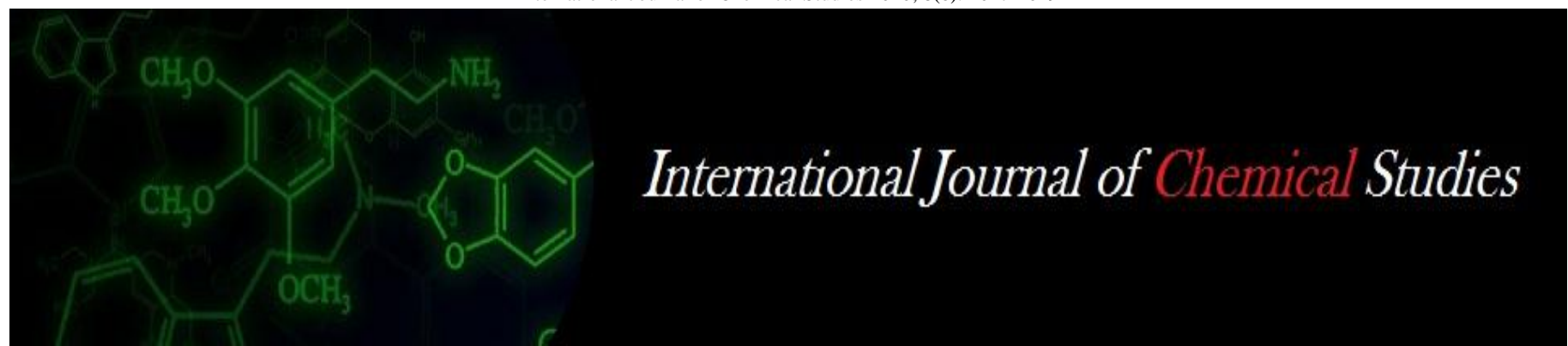

P-ISSN: 2349-8528

E-ISSN: 2321-4902

www.chemijournal.com

IJCS 2020; 8(6): 1027-1029

(C) 2020 IJCS

Received: 30-09-2020

Accepted: 04-10-2020

\section{Senapati SK}

Department of Fruit Science and

Horticulture Technology,

OUAT, Bhubaneswar, Odisha,

India

Sahoo SC

Department of Fruit Science and

Horticulture Technology,

OUAT, Bhubaneswar, Odisha,

India

\section{Mishra A}

Department of Soil Science and Agricultural Chemistry, OUAT,

Bhubaneswar, Odisha, India

\section{Mishra BK}

Department of Plant Physiology,

OUAT, Bhubaneswar, Odisha,

India

\section{Patel MK}

Department of Horticulture,

IAS, SoA, Bhubaneswar, Odisha, India

\section{Karna AK}

Department of Horticulture, IAS, SoA, Bhubaneswar, Odisha, India
Corresponding Author: Senapati SK

Department of Fruit Science and Horticulture Technology,

OUAT, Bhubaneswar, Odisha,

India

\section{Effect of integrated manuring and growth regulators on vegetative growth and flowering of pineapple (Ananas comosus L. Merr.)}

\author{
Senapati SK, Sahoo SC, Mishra A, Mishra BK, Patel MK and Karna AK
}

DOI: $\underline{\text { https://doi.org/10.22271/chemi.2020.v8.i6o.10898 }}$

\begin{abstract}
A trial was conducted to find out the best treatment combination for an experiment "Effect of integrated manuring and growth regulators on vegetative growth and flowering of pineapple" with an objective to get high, uniform vegetative growth and flowering in pineapple by integrated application of manure and growth regulators. The result revealed that $75 \%$ of recommended NPK $+25 \%$ of N through organic recycling with vermicompost along with NAA@10ppm, GA $@ 50$ ppm Ethrel@25ppm Perform best treatment combination with respect to physiological characters like, number of leaves per plant (49.19) number of leaves produced (3.96 per plant per month), chlorophyll a content $(0.385 \mathrm{mg} / \mathrm{g}$ fresh leaf), chlorophyll b content $(0.160 \mathrm{mg} / \mathrm{g}$ fresh leaf $)$ total chlorophyll content $(0.552 \mathrm{mg} / \mathrm{g}$ fresh leaf $)$, percentage of flowering $(92.76 \%)$, and maximum plant height $(82.28 \mathrm{~cm})$, length of D- leaf $(76.50 \mathrm{~cm})$, width of D-leaf $(6.14 \mathrm{~cm})$, with, leaf area $\left(273.17 \mathrm{~cm}^{2}\right)$. Flowering character like minimum number of days to flower initiation (42.84 days), minimum number of days required from flower initiation to fruit maturity ( 108.25 days) where significant variation found in $75 \%$ of recommended NPK $+25 \%$ of $\mathrm{N}$ through organic recycling with vermicompost along with NAA@10ppm.
\end{abstract}

Keywords: Pineapple, vermicompost, vermiwash, biofertlizer, vegetative, flowering, PGR

\section{Introduction}

Pineapple (Ananas comosus L. Merr) is an important herbaceous monocot crop belongs to the family Bromeliaceae. India is having an area of 103413 ha and production of 2593207tonnes $(F A O, 2011)^{[6]}$. In India, highest area under pineapple is in Assam (16.24 t/ha) and West Bengal leading the production with 310.00 million tonnes (Annual Report of NHB and Ministry of Agriculture Govt. of India 2017). Pineapple is a good source of carotene and ascorbic acid and is fairly rich in vitamins B and B2 (Lal and Pruthi, 1995) ${ }^{[8]}$. Fruit is high in the enzyme bromelain and the antioxidant vitamin C. It is a good source of dietary fiber. A major limitation that affects pineapple growers is the phenomenon of natural flowering, which results in unscheduled fruiting. All the plants do not flower at a time, over the whole field in one season. This causes not only great difficulty in the uniform harvesting of the crop but also keeps the land under the same crop for a longer time, thus, proper cultural requirements of the crop needs the immediate attention of the Horticulturists. Besides the use of the uniform planting materials and looking to proper and timely application of plant nutrient and water, the use of synthetic growth regulators have inspired workers for their practical use to induce uniform flowering and development of good quality fruits.

\section{Materials and Methods}

Accordingly, the present investigation entitled "Effect of integrated manuring and growth regulators on vegetative growth and flowering of pineapple (Ananas comosus L. Merr.)" The present investigation was carried out in the existing one year old pineapple plantation taken as a component crop in coconut based cropping system model in a paired row system of planting with $90 \times 60 \times 30 \mathrm{~cm}$ spacing conducted in the experimental site of All India Coordinated Research Project on Palms, Bhubaneswar operated under the Department of Fruit Science \& Horticulture Technology, College of Agriculture, OUAT, Bhubaneswar during July 2014 to June 2016. 
The experiment was conducted in a Split Plot Design with 18 different treatment with 3 replication combinations. Variety used as component crop in pineapple is "Queen" variety. Treatment combination are M1G1, M1G2, M1G3, M1G4, M1G5, M1G6, M2G1, M2G2, M2G3, M2G4, M2G5, M2G6, M3G1, M3G2, M3G3, M3G4, M3G5, M3G6. Where, M1 $100 \% \mathrm{~N}$ through organic recycling with vermicompost + vermiwash + biofertilizer (Azotobacter and Azospirillum), M2- $50 \%$ of recommended NPK $+50 \%$ of $\mathrm{N}$ through organic recycling with vermicmpost + vermiwash + biofertilizer (Azotobacter and Azospirillum), M3- 75\% of recommended $\mathrm{NPK}+25 \%$ of $\mathrm{N}$ through organic recycling with vermicompost and G1- NAA@10ppm, G2Ethrel@25ppm,G3-Ethrel@50ppm, G4 - GA3@ 50ppm, G5 -GA3@100ppm, G6 - Control (only water). Characters taken for this investigation are Plant height $(\mathrm{cm})$, No. of leaves per plant, No. of leaves produce per plant per month, Length of D-leaf $(\mathrm{cm})$, D-leaf width $(\mathrm{cm})$, Leaf area $\left(\mathrm{cm}^{2}\right)$, No. of days to flower initiation, No. of days to flower initiation, Percentage of flowering, Days required for flower initiation to fruit maturity with the objective to get uniform vegetative growth and flowering in pineapple by integrated application of manure and growth regulators.

\section{Result and Discussion}

In pooled data, it was observed that the maximum plant height $(82.28 \mathrm{~cm})$ was recorded in the treatment combination, $\mathrm{M}_{3} \mathrm{G}_{4}$ which was on par with $\mathrm{M}_{3} \mathrm{G}_{5}(82.02 \mathrm{~cm})$. The treatment combinations of $\mathrm{M}_{2} \mathrm{G}_{4}(81.33 \mathrm{~cm}), \mathrm{M}_{1} \mathrm{G}_{5}(81.13 \mathrm{~cm})$, where the minimum plant height $(68.05 \mathrm{~cm})$ was recorded in the treatment combination, $\mathrm{M}_{1} \mathrm{G}_{6}$ which was on par with $\mathrm{M}_{2} \mathrm{G}_{6}$ $(68.73 \mathrm{~cm})$ and $\mathrm{M}_{1} \mathrm{G}_{3}(69.30 \mathrm{~cm})$. This increase might be due to improvement of physical properties of soil through continuous supply of available nutrients from organic and inorganic sources. The similar result was reported by Bhowmick et al (2017) and Baraily and Deb (2018) [1] in pineapple and increase in cell elongation due to $\mathrm{GA}_{3} @ 50 \mathrm{ppm}$ application. Gibberellic acid promotes growth and elongation of cell. Similar results have been reported by Bhul et al. (1998) Belamcanda sinesis L.
It was noticed that highest number of leaves per plant (49.19) was recorded in the treatment combination $\mathrm{M}_{3} \mathrm{G}_{1}$ which was at par with the treatment combination $\mathrm{M}_{3} \mathrm{G}_{2}$ (48.20) and $\mathrm{M}_{2} \mathrm{G}_{1}$ (48.17) and the lowest number of leaves (36.46) was recorded in the treatment combination, $\mathrm{M}_{1} \mathrm{G}_{6}$. For effectiveness the number of leaves in pineapple has an important factor ad 3040 leaves are required for flowering of pineapple. Similar responses of increase in number of leaves per plant has been reported by Baraily and Deb (2018) ${ }^{[1]}$, Bhowmick et al., (2017), Liu et al. (2013) and Ortuchuwc and Adedokun (2014) in pineapple. The results are in conformity with the finding of Shrama (1970) who obtained higher number of leaves by the application of $\mathrm{GA}_{3}$ \& NAA in Kew pineapple.

The perusal of the pooled data indicated that the interaction effect of integrated manuring and growth regulator was nonsignificant with respect to number of leaves produced per plant per month. However, the maximum number of leaves produced (3.96 per plant per month) was recorded in the treatment $\mathrm{M}_{3} \mathrm{G}_{1}$ and the minimum number of leaves produce per month (2.88 per plant per month) was recorded in treatment $\mathrm{M}_{1} \mathrm{G}_{6}$. Organic recycling with vermicompost + vermiwash + bio-fertilizer). This is in line with the findings of Darnaudery et al., (2016). All plant growth regulators significantly influenced the rate of production of leaves in pineapple.

The two years pooled data presented in table 1 indicated that, significantly highest length of D- leaf $(76.50 \mathrm{~cm})$ was recorded in the treatment combination $\mathrm{M}_{3} \mathrm{G}_{4}$ and the lowest length of D-leaf $(61.43 \mathrm{~cm})$ was recorded in the treatment combination $\mathrm{M}_{1} \mathrm{G}_{6}$ which was followed by the treatment $\mathrm{M}_{2} \mathrm{G}_{6}(62.43 \mathrm{~cm})$.

The maximum width of D-leaf $(6.14 \mathrm{~cm})$ was recorded in the treatment combination $\mathrm{M}_{3} \mathrm{G}_{4}$ and was superior to rest of the treatment combinations. However, the minimum width of Dleaf $(4.15 \mathrm{~cm})$ was recorded in the treatment combination $\mathrm{M}_{1} \mathrm{G}_{6}$. It is clear from the table 1 that adoption of integrated manuring effective in increasing length of D-leaf through organic recycling with vermicompost). Similar result has been reported by Bhowmick et al., (2017) and Baraily and Deb (2018) ${ }^{[1]}$. The elongation caused by $\mathrm{GA}_{3}$ resulted from increased cell division and cell elongation.

Table 1: Effect of integrated manuring and growth regulators on vegetative growth and flowering of pineapple

\begin{tabular}{|c|c|c|c|c|c|c|c|c|c|c|c|c|}
\hline \multirow[b]{2}{*}{$\begin{array}{c}\text { Interaction } \\
\text { effect }\end{array}$} & \multicolumn{12}{|c|}{ Pooled data (2014-2016) } \\
\hline & $\begin{array}{c}\text { Plant } \\
\text { height } \\
(\mathbf{c m})\end{array}$ & $\begin{array}{c}\text { No. of } \\
\text { leaves } \\
\text { per } \\
\text { plant }\end{array}$ & $\begin{array}{c}\text { No. of } \\
\text { leaves } \\
\text { produce } \\
\text { per plant } \\
\text { per month }\end{array}$ & $\begin{array}{c}\text { Length } \\
\text { of D- } \\
\text { leaf } \\
(\mathrm{cm})\end{array}$ & $\begin{array}{l}\text { D-leaf } \\
\text { width } \\
\text { (cm) }\end{array}$ & $\begin{array}{c}\text { Chlorophyll a } \\
\text { Content in D } \\
\text { leaf }\end{array}$ & $\begin{array}{c}\text { Chlorophyll b } \\
\text { Content in D } \\
\text { leaf }\end{array}$ & $\begin{array}{c}\text { Total } \\
\text { Chlorophyll } \\
\text { in D leaf }\end{array}$ & $\begin{array}{c}\text { Leaf } \\
\text { area } \\
(\mathrm{cm} 2)\end{array}$ & $\begin{array}{c}\text { No. of } \\
\text { days to } \\
\text { flower } \\
\text { initiation }\end{array}$ & $\begin{array}{c}\text { Percentage } \\
\text { of } \\
\text { flowering }\end{array} \mid$ & $\begin{array}{c}\text { Days required } \\
\text { for flower } \\
\text { initiation to fruit } \\
\text { maturity }\end{array}$ \\
\hline M1G1 & 77.97 & 42.33 & 3.48 & 70.93 & 4.47 & 0.311 & 0.134 & 0.438 & 181.00 & 48.55 & 87.80 & 137.25 \\
\hline M1G2 & 71.63 & 40.62 & 3.12 & 65.30 & 4.42 & 0.225 & 0.119 & 0.340 & 175.50 & 45.82 & 68.00 & 112.25 \\
\hline M1G3 & 69.30 & 40.89 & 2.98 & 62.50 & 4.41 & 0.220 & 0.116 & 0.332 & 163.50 & 47.66 & 67.82 & 115.92 \\
\hline M1G4 & 80.55 & 38.24 & 3.35 & 73.27 & 5.23 & 0.215 & 0.113 & 0.330 & 204.83 & 65.55 & 64.40 & 150.92 \\
\hline M1G5 & 80.13 & 37.57 & 3.33 & 71.72 & 4.53 & 0.181 & 0.087 & 0.261 & 186.50 & 67.82 & 63.18 & 154.08 \\
\hline M1G6 & 68.05 & 36.46 & 2.88 & 61.43 & 4.15 & 0.155 & 0.080 & 0.240 & 148.17 & 70.93 & 61.12 & 119.58 \\
\hline M2G1 & 78.92 & 48.17 & 3.87 & 72.52 & 4.92 & 0.359 & 0.155 & 0.521 & 210.00 & 46.60 & 90.40 & 134.92 \\
\hline M2G2 & 78.32 & 46.10 & 3.40 & 71.15 & 5.17 & 0.315 & 0.146 & 0.461 & \begin{tabular}{|l|}
196.17 \\
\end{tabular} & 44.94 & 70.59 & 109.25 \\
\hline M2G3 & 77.55 & 44.57 & 3.18 & 70.07 & 5.00 & 0.245 & 0.128 & 0.377 & 178.00 & 45.90 & 70.27 & 111.92 \\
\hline M2G4 & 81.33 & 42.61 & 3.52 & 75.35 & 5.89 & 0.225 & 0.121 & 0.346 & 249.33 & 64.83 & 68.59 & 140.92 \\
\hline M2G5 & 80.85 & 41.14 & 3.53 & 74.40 & 5.41 & 0.220 & 0.106 & 0.323 & 221.67 & 66.83 & 64.69 & 144.25 \\
\hline M2G6 & 68.73 & 38.36 & 2.98 & 62.43 & 4.33 & 0.172 & 0.101 & 0.270 & 153.00 & 69.84 & 62.60 & 116.92 \\
\hline M3G1 & 81.00 & 49.19 & 3.96 & 74.80 & 5.69 & 0.385 & 0.160 & 0.552 & 213.83 & 44.56 & 92.76 & 132.91 \\
\hline M3G2 & 80.63 & 48.20 & 3.75 & 73.82 & 5.61 & 0.345 & 0.157 & 0.497 & 191.83 & 42.84 & 72.14 & 108.25 \\
\hline M3G3 & 77.55 & 47.45 & 3.53 & 71.52 & 5.31 & 0.292 & 0.136 & 0.431 & 168.67 & 44.89 & 71.19 & 112.25 \\
\hline M3G4 & 82.28 & 45.05 & 3.88 & 76.50 & 6.16 & 0.275 & 0.122 & 0.400 & 273.17 & 64.14 & 70.74 & 134.24 \\
\hline M3G5 & 82.02 & 42.30 & 3.85 & 75.50 & 5.80 & 0.221 & 0.112 & 0.331 & 244.17 & 66.17 & 67.78 & 137.58 \\
\hline M3G6 & 71.71 & 40.26 & 3.30 & 64.35 & 4.92 & 0.175 & 0.106 & 0.281 & 154.00 & 69.87 & 65.55 & 115.91 \\
\hline $\mathrm{SE}(\mathrm{m}) \pm$ & 0.275 & 0.406 & 0.076 & 0.300 & 0.014 & 0.001 & 0.001 & 0.002 & 8.996 & 0.680 & 0.759 & 1.918 \\
\hline $\mathrm{CD}(\mathrm{P}=0.05)$ & 0.863 & 1.396 & $\mathrm{NS}$ & 0.935 & 0.044 & 0.006 & 0.003 & 0.007 & 26.189 & NS & 2.201 & 5.602 \\
\hline
\end{tabular}


It was indicated that the maximum chlorophyll a content $(0.385 \mathrm{mg} / \mathrm{g}$ fresh leaf) was estimated in the treatment combination $\mathrm{M}_{3} \mathrm{G}_{1}$. the minimum value of chlorophyll $A$ content $(0.155 \mathrm{mg} / \mathrm{g}$ fresh leaf) was estimated in the treatment combination $\mathrm{M}_{1} \mathrm{G}_{6}$.

It was indicated that maximum amount of chlorophyll $b$ content $(0.160 \mathrm{mg} / \mathrm{g}$ fresh leaf $)$ was estimated in the treatment combination, $\mathrm{M}_{3} \mathrm{G}_{1}$. Whereas, the minimum amount of chlorophyll b $(0.080 \mathrm{mg} / \mathrm{g}$ fresh leaf $)$ was recorded in the treatment combination $\mathrm{M}_{1} \mathrm{G}_{6}$.

It was observed that the treatment combination $\mathrm{M}_{3} \mathrm{G}_{1}$ was statistical significantly superior to all other treatments by resulting maximum amount of total chlorophyll content ( $0.552 \mathrm{mg} / \mathrm{g}$ fresh leaf) $\mathrm{M}_{3} \mathrm{G}_{1}$. The minimum amount of total chlorophyll content $(0.240 \mathrm{mg} / \mathrm{g}$ fresh leaf $)$ was estimated in the treatment combinations $\mathrm{M}_{1} \mathrm{G}_{6}$.

The chlorophyll content in leaves indicates the efficiency of photosynthesis, where the solar energy is converted into chemical energy and N,P \& K were utilized efficiently by the plant, which resulted in producing plant biomass and translocation of the assimilated materials to the developing sink. The role of nitrogen and potassium in the functioning of chlorophyll has been established. These results were in accordance with results reported by kuttimani et al., (2013) in papaya. In general, treated plants registered more photosynthesis rate as reported by Liu et al., (2013), Baraily \& Deb (2018) ${ }^{[1]}$ in pineapple. The plant growth regulators had significant effect in chlorophyll contents of D-leaf of pineapple. The present findings are in conformity with the findings of AO Bhowmick et al., (2017) in pineapple.

The maximum leaf area $\left(273.17 \mathrm{~cm}^{2}\right)$ was observed in the treatment combination and the minimum leaf area $\left(148.17 \mathrm{~cm}^{2}\right)$ was found in the treatment combination $\mathrm{M}_{1} \mathrm{G}_{6}$. Leaf area is an important growth indication determining the capacity of plant to trap solar energy for photosynthesis and has marked influenced on growth and yield of plant through organic recycling with vermicompost. $\mathrm{GA}_{3}$ increased the leaf area by multiplying, elongation and enlargement of cell.

Data depicted in table 10 (C) clearly indicated that the interaction effect of integrated manuring and growth regulator was quite non-significant with respect to earliness in flowering in pineapple. However, minimum number of days to flower initiation (42.84 days) was recorded in the treatment combination of $\mathrm{M}_{3} \mathrm{G}_{2}$ during the year in pooled data whereas longer time take for flower initiation in the treatment 69.87 $\left(\mathrm{M}_{3} \mathrm{G}_{6}\right)$ which is at par with $69.84\left(\mathrm{M}_{2} \mathrm{G}_{6}\right)$. The application of ethrel@25ppm induced early flowering compared to other treatment. Similar results are in conformity with the finding reported by Hassain et al., (2008) and Pal et al., (2015) ${ }^{[11]}$ in pineapple.

Maximum percentage of flowering $(92.76 \%)$ was recorded in the treatment combination $\mathrm{M}_{3} \mathrm{G}_{1}$ and the minimum percentage of flowering $(61.17 \%)$ was recorded in the treatment combination $\mathrm{M}_{1} \mathrm{G}_{6}$ also. Its is due to organic recycling with vermicompost + vermiwash + bio-fertilizer. This line with the studies of Baraily \& Deb (2018) ${ }^{[1]}$ in pineapple. Similar resultsare in agreement with those Ghosh et al., (2013) ${ }^{[2]}$ and Bhowmick et al., (2017) in pineapple.

NAA affect the development of development of anthers that appear to influence corolla development and pigmentation. Inhibition of auxin biosynthesis can delay anthesis while exogenous auxin have the inducing effect of flowering in pineapple. Similar results of percentage of flowering have been reported by Pal et al., (2015) ${ }^{[11]}$ in pineapple.

It was observed that the minimum number of days required from flower initiation to fruit maturity (108.25 days) was recorded in the treatment combination $\mathrm{M}_{3} \mathrm{G}_{2}$, where maximum number of days taken from flower initiation to fruit maturity $\mathrm{M}_{1} \mathrm{G}_{5}$ (154.25 days) was recorded in the treatment combination.

This may be due to increase in the availability of nitrogen in soil resulting the earlier in flower initiation to fruits maturity (Liu \& Liu 2012) ${ }^{[9]}$ in pineapple. Fruit maturity period was delayed due to different growth regulators. The earlier in fruit maturity due to ethers treatment was reported by $\mathrm{Pal}$ et al $(2015)^{[11]}$ in pineapple.

\section{Conclusion}

The salient findings of the present study entitled "Effect of integrated manuring and growth regulators on vegetative growth and flowering of pineapple" clearly reveals that significant variation found in treatment $\mathrm{M}_{3} \mathrm{G}_{1}-75 \%$ of recommended NPK $+25 \%$ of $\mathrm{N}$ through organic recycling with vermicompost + NAA@10ppm with respect to number of leaves per plant, number of leaves per plant per month, chlorophyll a, chlorophyll $\mathrm{b}$, total chlorophyll, percentage of flowering and $\mathrm{M}_{3} \mathrm{G}_{2}-75 \%$ of recommended NPK $+25 \%$ of $\mathrm{N}$ through organic recycling with vermicompost + Ethrel@25ppm with respect to no. of days to flower initiation, Days required for flower initiation to fruit maturity with $\mathrm{M}_{3} \mathrm{G}_{4}$ $-75 \%$ of recommended NPK $+25 \%$ of $\mathrm{N}$ through organic recycling with vermicompost $+\mathrm{GA}_{3} @ 50 \mathrm{ppm}$ show good result on plany height, length and weidth of $\mathrm{D}$ leaf and leaf area.

\section{Reference}

1. Baraily P, Deb P. Effect of integrated nutrient management on growth and yield of pineapple (cv. Kew). International Journal of Chemical Studies. 2018; 6(5):1691-1695.

2. Bhomick N, Ghosh SK, Munsi PS, Deb P, Ghosh A. Effect of integrated nutrient management on flowering and fruiting characteristics of pineapple.cv. Mauritius. Journal of Crop and Weed. 2017; 13(2):144-156.

3. Biswal SR, Das AK, Mishra N, Sahoo AK, Mishra PP. Effect of nutrition and growth regulators application on pineapple (Ananas comosus L. Merr) under Costal Zone Odisha. Green Farming, 2015; 6(5):1071-1073.

4. Bose TK, Mitra SK, Sen SK. Regulation of flowering in pineapple the year round. Indian Agricultural Research, 1983; 27(4):331-336.

5. Bowden RP. Effect of Napthalene acitic acid on the processing quality of pineapple. Food Science and Technology, Abstract. 1969; 21(9):454-457.

6. FAO. Fertilizer and their use, FAO Rome Italy.

7. Isuwan Auraiwan, 2014. Agronomic traits and fruit quality of pineapple with different levels of chicken manure application. Silpakorn U Science and Tech Journal. 2008; 8(1):67-73.

8. Lal G, Pruthi JS. Ascorbic acid retention in pineapple product, Indian Journal of Horticulture. 1995; 12:137141.

9. Liu $\mathrm{CH}$, Liu Y. Influences of organic manure addition on the maturity and quality of pineapple fruits ripened in winter. Journal ofSoil Science and Plant Nutrition. 2012; 12(2):211-220.

10. Maibangsa S, Ahmed F. Effect of post flowering spray with NAA and GA3 on ratton pineapple. Annuals Agricultural Research. 2000; 21(1):133-134.

11. Pal R, Mahato SK, Chhetri, Binoy, Suresh CP. Growth regulators influencingyield and quality of pineapple (Ananas comosus L. Merr). Eco. Env and Cons. 2015; 21(2):879-884.

12. Santa KK, Aravidakshan M, Namboodiri KM. Effect of different chemicals on flowering and fruiting development in pineapple. South Indian Horticulture. $1983 ; 31(4,5): 181-186$. 